\title{
Characteristics of infants born to mothers with autoimmune disorders
}

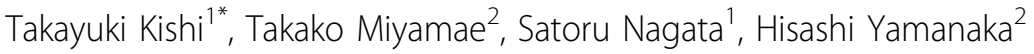 \\ From 21st European Pediatric Rheumatology (PReS) Congress \\ Belgrade, Serbia. 17-21 September 2014
}

\begin{abstract}
Introduction
Autoimmune diseases frequently affect women of childbearing age. Gravidas with autoimmune diseases have a tendency to develop complications, such as pregnancy-induced hypertension in pregnancies complicated by systemic lupus erythematosus (SLE). The activity of autoimmune diseases is often exacerbated during pregnancy. The transplacental passage of autoantibodies may have an effect on the fetus or neonate; congenital heart block, in particular, is often irreversible. Therefore, increased vigilance is required for pregnancies complicated by autoimmune disorders.
\end{abstract}

\section{Objectives}

Herein the characteristics of newborns from mothers with autoimmune disorders were evaluated.

\section{Methods}

Clinical manifestations were assessed in 40 newborn infants from 38 mothers with autoimmune disororders (20 with SLE, 10 with rheumatoid arthritis, 6 with antiphospholipid syndrome, 6 with Sjogren's syndrome, 4 with screloderma, 1 with mixed connective tissue disease, and 1 with juvenile dermatomyositis) who attended the Tokyo Women's Medical University Hospital between January 2011 and November 2013. The following information deriverd from the patients' charts was reviewed: maternal autoimmune disease, maternal autoantibodies, medications prescribed during pregnancy, gestational age (GA), and autoantibodies transferred to the infant.

\section{Results}

The average age of the mother at the time of the delivery was 33.7 years. Twenty mothers had anti-Ro/SS-A, 5 had

'Department of Pediatrics, Tokyo Women's Medical University, Tokyo, Japan Full list of author information is available at the end of the article
anti-La/SS-B, and 4 had anti-RNP antibodies. Twenty-two gravidas $(57.9 \%)$ were treated with oral glucocorticoids (GC) during pregnancy. The average dose of predonisolone and methylprednisolone was $10.8 \mathrm{mg} /$ day $(2-30 \mathrm{mg} /$ day) and $8.0 \mathrm{mg} /$ day (4-16 mg/day), respectively. Four gravidas with SLE used immunosuppresants (cyclosporine $[n=2]$, tacrolimus [ $n=2])$. Seven of 38 gravidas (18.7\%) were delivered by emergency cesarean section. The average GA at birth was 36 3/7 weeks (23 6/7-41 1/7 weeks) and 17 of 40 (42.5\%) had preterm births. Four of 23 term newborns met the criteria for small for gestational age (SGA). The average birth weight was $2314 \pm 649 \mathrm{~g}$ (range, 508-3676 g), and included 23 low birth weight (LBW) newborns (57.5\%) and 3 extremely LBW newborns (7.9\%). When the gravida used GC during pregnancy, there were significantly higher rates of preterm births and SGA neonates $(p<0.05)$. The birth weights and GAs were not significantly different between gravidas with and without SLE. The average GA and birth weight of newborns whose mothers were treated with GC was $355 / 7$ weeks and 2131 $\pm 704 \mathrm{~g}$, respectively, suggesting that GC may be a factor that affects GA and birth weight. Autoantibodies were detected in 18 infants (anti-Ro/SS-A [18/20;90\%] and anti-La/SS-B [3/5;80\%]). One baby had congenital complete heart block. Rash, thrombocytopenia, and hypertransaminasemia (ALT > $35 \mathrm{U} / \mathrm{l}$ ) developed after hospital discharge in 1, 3, and 4 infants, respectively. With respect to neonates born to antiSS-A antibody-positive mothers, maternal GC use or non-use had no effect on the incidence of autoantibodies and infant symptoms. There were no infants who developed congenital heart block born to mothers who had used prednisolone during pregnancy.

\section{Conclusion}

The probabilities of preterm delivery and LBW infants were higher and more remarkable in gravidas treated with GC. Further research is needed to better understand 
how maternal autoimmune disease activity influences the fetus and neonate. Continued observation by pediatricians is important until autoantibodies are cleared in the infant.

\section{Disclosure of interest}

None declared.

\section{Authors' details}

'Department of Pediatrics, Tokyo Women's Medical University, Tokyo, Japan. ${ }^{2}$ Institute of Rheumatology, Tokyo Women's Medical University, Tokyo, Japan.

Published: 17 September 2014

doi:10.1186/1546-0096-12-S1-P115

Cite this article as: Kishi et al:: Characteristics of infants born to mothers with autoimmune disorders. Pediatric Rheumatology 2014

12(Suppl 1):P115.
Submit your next manuscript to BioMed Central and take full advantage of:

- Convenient online submission

- Thorough peer review

- No space constraints or color figure charges

- Immediate publication on acceptance

- Inclusion in PubMed, CAS, Scopus and Google Scholar

- Research which is freely available for redistribution

Submit your manuscript at www.biomedcentral.com/submit
C Biomed Central 